исполнительная власть США, законодательная власть США, президент США, Конгресс США, создание правовых норм.

\title{
SUPREME COURT OF THE USA UNDER THE DIRECTION OF HUGHES Ch. E. (1930-1941)
}

The role of Supreme Court of the USA is investigated in the article - to the higher federal judicial instance in forming of the system of right in 1930-1941 (in the period of chairmanship of judge Hughes Ch. E.), and also influence in this period of federal department judicial on executive and legislative power and legal system of the state. The role of Supreme Court of the USA is also determined in forming of constitutional device of the USA, creation of precedent that in future was used by Presidents of the USA in their activity. Conclusions and recommendations are offered.

There is research of position the USA in 1930-1941 it is actual not only because of that at this time measures were conducted on overcoming of world economic crisis, but also because Supreme Court of the USA entered into a peracute (for all history) conflict with executive sovereignly - President.

Supreme Court as general and constitutional justice court, must (in case of origin of legal dispute) analysing positions of laws that in opinion of side in business are unconstitutional to define a question about their accordance of federal Constitution.

So there is a necessity to find out, going round ideological conclusions, real historical and legal role of Supreme Court of the USA chaired by Hughes Ch. E. in forming of the system of right constitutional mode, and also about actual character of political and legal mutual relations between federal judicial, executive and legislative authorities.

Key words: Supreme Court of the USA, federal department judicial, "New Deal» of President F. D. Roosevelt, system of right, state interference with an economy, executive power of the USA, legislature of the USA.

УДК 340.12

Співак B. B., кандидат філософських наук, докторант Національної музичної академії України імені П. І. Чайковського, м. Київ

\section{ПОЛІТИКО-ПРАВОВІ КАТЕГОРІЇ ЯК МАРКЕР ІДЕНТИЧНОСТІ В СПАДЩИНІ АНТОНІЯ РАДИВИЛОВСЬКОГО}

У статті досліджено проблему політичної ідентичності Антонія Радивиловського на підставі аналізу політико-правового категоріального апарату філософської складової його проповідницької спадщчини. Зроблено висновок про еклектичність його політичного світогляду, в якому поєднуються образи та категорї політичного життя Русі-України, Речі Посполитої, Війська Запо- 
різького та Московського ичарства. Виявляючи лояльність до монарха, як образу вищої влади, проповідник схиляється до ідей республіканізму.

Ключові слова: українська філософія, філософія права, політична філософія, бароко, ідентичність, самовладдя, республіканізм.

Постановка проблеми. Друга половина XVII століття в Україні відзначилася бурхливими суспільно-політичними струсами, які викликали зміни в соціальній структурі суспільства й політичній сфері та справили вплив і на духовне життя. В останньому провідну роль відігравала церква на чолі з плеядою інтелектуалів, вихованих «могилянськими» реформами: Інокентієм Гізелем, Лазарем Барановичем, Іоаникієм Галятовським, Антонієм Радивиловським та ін.

Їх тексти представлені полемічними творами, трактатами 3 морального богослов'я для священиків, віршами та проповідями, що покликані дати уявлення про істини віри, християнську мораль, прославити справи «відомих» людей, дати відповідь на критику з боку іноконфесійних конкурентів тощо.

Але разом $з$ основною метою під час створення свого «продукту» автори свідомо чи несвідомо виявляли певну політичну заангажованість, висловлюючи прямо чи опосередковано ідеї, що стосуються уявлень про владу, державу, право та політичний устрій суспільства, що відносяться до сфери політичної та правової філософії. Такі ідеї проявлялись у вигляді похвали за мудре правління, жалкування про сучасні «оплакані часи», розбору «гріхів і цнот», властивих носіям влади, моральних історійприкладів, спеціальних міркувань про належний порядок та інших, інколи доволі несподіваних формах.

Формулювання цілей статті. Спроба визначити природу такої строкатості та суті, що криється за нею, є метою цієї розвідки. Джерелами дослідження обрано проповіді Антонія Радивиловського, який є знаковою особою своєї епохи та здатен репрезентувати політико-правовий світогляд представників церковної інтелектуальної еліти епохи бароко. При цьому планується звернути увагу на політичний порядок, з яким себе ідентифікує проповідник, що дозволяє виявити прихильність автора до тих чи інших політико-правових ідей. Таке дослідження може доповнити наші уявлення про ідейний арсенал політичної та правової філософії українських мислителів епохи бароко. 
Аналіз останніх досліджень 3 теми. Ця проблематика вже розглядалася у багатьох працях вітчизняних та зарубіжних дослідників, таких як: Довга Л. М. [3], Яковенко Н. М. [9], Когут 3. [4] тощо. Названі дослідники звертали увагу на деякі особливості політико-правової ідентичності української політичної та інтелектуальної еліти 2 пол. XVII ст. Проте на матеріалах проповідей Антонія Радивиловського вона розглянута недостатньо. Тож ця проблема потребує більш детальної уваги.

Виклад основного матеріалу. Загальна політико-правова теорія у творчості українських церковних мислителів епохи бароко, природно, спирається на церковну доктрину, що синтезувала в собі доробок отців церкви та деякі ідеї античності. Крім цього, також трапляються репліки ідей, запозичених з праць світських авторів епохи Відродження (зокрема Гуго Гроція, Еразма Ротердамського та ін.).

При цьому церковні інтелектуали виявляють доволі строкаті політико-правові орієнтації, які являють собою конгломерат різноманітних ідей, часто суперечливих та навіть взаємовиключних, що поєднують у собі елементи традиційної політичної культури Речі Посполитої, руського та литовського права 3 політикоправовими уявленнями козацької старшини й апеляціями до московської «самовладної стабільності».

Останні є характерними для церковних ієрархів, що може трактуватися як загальний настрій духовенства стосовно московського царя, що «видавався їм гарантом спокою та стабільності, на відміну від розбурханої міжусобицями старшинської еліти» [10, с. 434], оскільки данина тогочасній традиції письменства, що передбачала висловлення лояльності до вищої політичної влади та патронівспонсорів, яка зі змінами у суспільно-політичній ситуації почала переноситися з короля та магнатів на царя й гетьманів.

Тож формулу, вміщену Антонієм Радивиловським на початку друкованого «Вінця Христова» 1688 року, яка характеризує московських царів Івана і Петра Олексійовичів та царівну Софію як «Прєсвітлішихъ Дєржавнійшихъ и Благочєстивійшихъ Вєликихъ Государєй нашихъ Царєй й Вєликихъ Князєй...» [5, арк. 2], а самого автора як: «Нєдостойный Книги сєя... Ділатєль, Всєгдашній... Вашєго Царскаго Прєсвітлаго Вєличєства Богомолєцъ, ни- 
жайшїй рабъ й подножїє...» [5, арк. 11], можна вважати не стільки проявом «безумовної відданості підданого», скільки дотриманням письменського етикету стосовно осіб, що являють собою символ вищої державної влади. На користь цього припущення свідчить повторення тут проповідником загальноприйнятої дипломатичної формули звертання до царя, що перекочувала у збірку церковних проповідей з суспільно-політичного дискурсу.

Далі Антоній Радивиловський традиційно наділяє царську родину всіма християнськими цнотами, головною з яких є захист православ'я - «понєжє Віру святую Православнокафоличєскую... распространяєтє, й повсюду туюж дє защищаєтє...» $[5$, арк. 12]. Як відомо, саме «православність» московського царя була однією $з$ причин проявів симпатій до нього з боку українського духовенства, а акцент на захисті віри та церкви як місії російських царів був характерний для всіх церковних інтелектуалів 2 пол. XVII ст. [10, с. 434-435].

Крім цього, церковні ієрархи прагнули знайти в особі царя: покровителя, спонсора й захисника від інтриг конкурентів, на що розраховує у своїй посвяті й Антоній Радивиловський - «аз нєдостойный ділатєль, сице й сєй трудъ мой, под покровєнїємъ Вашєго Царскаго Прєсвєтлаго Вєличєства, могль сохранєнъ быти отъ всякихъ злословїй бєзбіднє, й да с нимъ нє убоюся зла, яко Вашє Царскоє Прєсвітлоє Вєличєство Прєблагіи мои защитници єстє» [5, арк. 16].

Усі вищезазначені положення, що висловлюють підкреслену лояльність до царської влади, є цілком природними з точки зору традиційної позиції православної церкви щодо держави, відповідно до формули - «нема влади не від Бога» (Рим. 13, 1). Тож церква постійно шукала підтримки та лояльності з боку держави, хоча, 3 іншого боку, кожен церковнослужитель був відданий більше «небесній вітчизні», ніж земному володарю. Так, у своїх рукописах Радивиловський наводить таке міркування - (завбачливо викреслене в друкованому варіанті «Вінця Христова» 1688 року) - «Что єст Цръ? Что монарха? члкъ єстъ. а члкъ что? Єсть тінь, сонъ» [6, с. 361], далі проповідник пише, що варто служити Богу, а не можновладцям. 
Так само, як у 2 пол. XVII ст. церковні письменники одноголосно звеличували «царську величність», раніше православна церква в Україні шукала підтримки королівської влади та магнатських родин. 3 прийняттям зверхності московської влади змінився лише об'єкт вшанування та формальне наповнення його вираження, самі ж засоби та суть такої апеляції залишаються в межах попередньої традиції церковного письменства (звеличення цнот володаря, його герба, діянь, прохання про патронаж). Тож вихваляння царських осіб навряд чи є виразом виключної прихильності до Москви чи до московських порядків, скоріше це $\epsilon$ проявом бажання дотриматись етикету чи знайти міцний грунт під ногами та гарантії безпеки у неспокійні часи.

Крім «московського» орієнтиру, в текстах Радивиловського трапляється багато маркерів політичного життя Речі Посполитої. Так, проповідник описує суспільно-політичний устрій «граду земного», що є калькою з річпосполитського світу, в якому формувався автор. Наприклад, звертаючись до суспільної моральної проблематики, Радивиловський згадує: «станъ Царскій, станъ Сєнаторскій, станъ Воинскїй, станъ Радєцкїй... сєнаторъ на кріслі сєнаторскомъ сидячи, прагнєтъ примножєнъя староствъ, прагнєть булавы Гєтманской, Пєчати канцлірской, ласки Маршалковской» [6, с. 123]; «в Рєчи Посполитой, нє вси єдиним ся здобят титулом, алє кто Воєводою, Кашталяномъ, кто Старостою, Скарбникомъ, подскарбимъ [7, с. 696]. Поданий тут перелік «урядів» містить такі, що невластиві ані Московському двору, ані Війську Запорізькому, але цілком «свої» як для автора, так і сучасників.

Антоній Радивиловський широко використовує у своїх повчаннях правові категорії Речі Посполитої, наприклад: «обваровал тоє псалмиста страхом, нібы якою сєймовою конституцією, рєкши...» [6, с. 336]. Саме ж право користується у проповідника високим авторитетом. Так, він висловлює ідею підпорядкування влади правовим нормам, що є характерним для уявлень Речі Посполитої - місто перебуває в цілісності - «кгды житєлїє онаго будуть послушными бурмистром, бурмистры зась правомъ» [6, с. 510].

Цікавим $\epsilon$ те, що ці категорії, присутні в наведених уривках 3 рукописного «Вінця Христова», пізніше були підчищені у дру- 
кованому «Вінці Христовому» 1688 року [5, арк. 36 зв.-37; арк. $116]$, що говорить про намагання автора зробити його більш «політкоректним». Але, незважаючи на таку редакцію, політикоправові категорії Речі Посполитої продовжують рясніти і в друкованих збірках Антонія Радивиловського - «Нє знаєть натура срожитися на Річъ Посполитую» [5, арк. 519 зв.]; «єдного разу учинили сєбі сеймъ» [5, арк. 541 зв.]; «посєлства своєго рєляцїю албо отнєсєнє чинилъ» [7, с. 1118].

Описуючи царські цноти (Антоній Радивиловський фактично не згадує короля та не вживає цей термін для позначення монарха), проповідник наділяє монаршу особу всіма належними їй християнськими чеснотами [5, арк. 12; 7, с. 274-275]. Проте такий «цар» володіє рисами, які характеризують його не як «московського самовладця», а, скоріше, як монарха зі світу політикоправових уявлень Речі Посполитої [5, арк. 524 зв.; 6, с. 1419]. Так, проповідник змальовує просування особи по кар'єрній драбині на різні «уряды», причому така кар'єра завершується обійманням «царського уряду», що є більш характерним для порядків Речі Посполитої, ніж московського політичного життя: «Нєхай кто вси пєрєйдєт уряды сєго мира; ... нєхай кто будєт на дворє Царскомъ покоєвымъ, потымъ нєхай будєтъ Сєкрєтаромъ, потымъ нєхай будєт Маршалком, нєхай будєт ротмистром, Полковником, Гєтманом, Сєнатором яким высоким; наостаток нєхай зостанєт й Царємъ...» [6, с. 753-754]. У друкованому «Вінці» Антоній Радивиловський прямо пише про вибори народом особи на роль царя, князя або «старшинство» та бажані критерії вибору кандидата - «гды кого людъ посполитый избираєть на якоє Царство, на Княжєнїє, албо на иншоє якоє старшинство, нєповинни усмотровати на позвірховную єго уроды пієнкность, а ни на родовитость фамілїи; алє на цноты, на укладность пристойныхъ, обычаєвъ, на смирєнїє, на побожность, на щодробливость й ласкавость. Тыи цноты оздобою суть Маєстату Царского, тыи цноты суть сохранєнїємъ живота єго» [7, с. 249]. Тож поняття «цар» у текстах Антонія Радивиловського, скоріше за все, $\epsilon$ «московським» лише за формою, а не за змістом.

Щодо самого тлумачення поняття «Річ Посполита» (відома польська калька $з$ латинського «республіка»), то цілком ймовірно 
для Антонія Радивиловського Річ Посполита є не тільки як Литовсько-Польська держава, а як синонім держави-суспільства взагалі. Він часто згадує «добро Речі Посполитої» як спільне благо чи громадське майно (як це зрозуміло з контексту), також використовує це поняття в тих місцях, де ця назва в загальновідомому сенсі $є$ явно недоречною, наприклад, у повчанні, присвяченому святому князю Володимиру - «Святый Вєликій Княжє Нашъ Россійскій Владимїрє, гдысь самъ з сєбє добрый приклад до прийнятя віры // Христовой всіму Россійскому народу подалъ, памяталєсъ на тоє, жє яко над злый приклад Царя албо Князя нічого нємашъ Рєчи Посполитой заразлившого й шкодлившого; такъ над добрый приклад Царя албо Князя нічого нємашъ той жє Рєчи Посполитой здоровшого, й пожитєчнійшого...» [7, с. 249250]. Тут, очевидно, під Річчю Посполитою мається на увазі держава як така, що говорить про прихильність до республіканських порядків взагалі, а не до політико-територіального утворення, що носило цю назву.

Політико-правові реалії Війська Запорізького також знайшли своє відображення в повчаннях Антонія Радивиловського. Проте вони значно менше представлені порівняно 3 річпосполитськими. Так, гетьмана Антоній Радивиловський у своїх повчаннях як самовладного володаря не згадує, надаючи йому роль військового лідера та риси християнина, властиві кожній людині високого стану. Цар та гетьман у переліку суспільної еліти, зазвичай, йдуть поруч із властивими їм спільними та відмінними цнотами: «Ссли єстєсь Цръ, памятайжє на тоє, жє тя Богъ для того на Прєсвітломъ Царскомъ посадилъ Маєстатє, абысь тыхъ которыи тєбє служать... многими опатроваль добродєйствы... //... Єсли єстєсь Гєтманъ, памятай жє на тоє, абысь нічого бєз уваги и рады нє чинилъ... абы воинов своих доброчиностю до послушєнства сєбє потягаль, абысь крывды в тягнєню людємъ чинити нєдопущалъ, абысь славу рєчи посполитой прєкладалъ над славу свою власную, абысь справєдливость заховалъ...» [6, с. 1404-1405]. В інших випадках гетьман також йде після царя, що може говорити про його підпорядковану роль у політичній свідомості Антонія Радивиловського.

Про особливий статус гетьмана в повчаннях проповідника могло б побіжно свідчити те, що він досить часто називає геть- 
маном Ісуса Христа, якого традиційно церква іменувала Царем Небесним. Так, у рукописному «Вінці Христовому» Радивиловський називає Христа гетьманом [6, с. 144], замінивши у друкованому варіанті на Царя [5, арк. 46]. В іншому місці проповідник називає Христа одночасно Царем та Гетьманом - «Христос Спситєль ... Црь над Царями, такъ Гєтманъ над Гєтманы [6, c. 1303]. Оскільки земний цар мав бути образом Царя Небесного, то у випадку порівнянням Христа й гетьмана цей «Imago Dei» міг б переноситися й на останнього, разом із наданням відповідного статусу земного володаря, влада якого священна.

Проте слід зауважити, що ці порівняння не є чимось унікальним як в українській традиції того часу, так і поза нею. Порівняння Христа та гетьмана $є$ характерним й для інших церковним мислителів 2 пол. XVII ст. Так, зокрема, гетьманом називає Христа Іоанікій Галятовський - «Ссть Христосъ, гєтманомъ валєчнымъ» [2, с. 119].Таке порівняння Христа 3 воєначальником (у тогочасній українській традиції - гетьманом) є характерним для образу «Церкви воюючої» та $є$ давньою традицією християнського письменства. Тож, зважаючи на те, що Христос був взірцем для кожного християнина, який мав «ревновати» йому у цнотах, питання про можливий особливий статус Гетьмана стосовно царської влади у системі політико-філософської складової повчань Антонія Радивиловського залишається відкритим.

3 інших маркерів суспільно-політичного життя гетьманської України присутній перелік «урядів» Війська Запорізького: «припомнитє собі... Гєтмановъ, Полковниковъ, Сотниковъ, Асауловъ, й иншихъ... Запорожцовъ...» [8, с. 39]. Також проповідник неодноразово описує ради воїнів з різних питань [7, с. 59], що є характерним для козацької спільноти. Втім під опис «рицарського кола» підпадає й феномен сеймиків та сеймів Речі Посполитої.

Цікавим у політико-філософській складовій повчань Антонія Радивиловського $є$ факт змішування проповідником в одному місці політико-правових категорій різних політичних порядків, особливо під час опису суспільної еліти: - «мыслити бовімъ быти [в рєчи Посполитой Князємъ, Сєнаторомъ, Старостою, на дворі Царском быти Маршалком, Канцліром, Каштеляном... мыслити быти в Войску Гєтманом, Полковником, Ротмистром, албо сотником, 
обозным, Писаром, а заж то нє золотая мысль?...» [6, с. 201] (у друкованому «Вінці Христовому» цей перелік відсутній [5, арк. 65]); «Князі, Воєводы, Сєнаторовє, Гєтмановє, поборцы, Старостовє, й прочая» [6, с. 567]; «пойзришъ в станъ Црскій, Сєнаторскій, Княжіій, Воєводскій, пойзришъ в станы Рыцєрскїє, яко то в станъ Гєтманскій, Полковницкій, Судєйскїй» [6, с. 202]; «учинятъ єго Паномъ вєликімъ, учинят єго Боляриномъ, Каштеляномъ, воєводою, Гєтманомъ, полковникомъ; учинятъ єго війтом, бурмистром, райцею, лавником и прочая...» [6, с. 677]; «въ дворахъ Царскихъ, сєнаторскихъ // княжихъ, болярскихъ, Гєтманскихъ, Полковничихъ й иншихъ, навіть в домахъ войтовских, бурмистровских, рєдєцкихъ...» [6, с. 1117-1118].

Тут ми бачимо перелік «значних урядів» Речі Посполитої, Війська Запорізького та Московського царства. Таке змішування категорій «старого» та «нового» політичних порядків говорить про властиву всій бароковій культурі «еклектичність» політичного світогляду Антонія Радивиловського, що була характерною й для інших його сучасників [9, с. 371-398]. Природою такої еклектики можна вважати: ментальні особливості автора, що інтелектуально сформувався ще до козацької революції під впливом «могилянського оновлення»; свідому чи несвідому корекцію політичних уявлень та образів, що їх передають залежно від кон'юнктури політичного життя; а також - особливу здатність світогляду «людини бароко» поєднувати в єдине ціле навіть непоєднуване з нашої точки зору (що стосується і образів, і ідей).

Висновки. Отже, звертаючись до політичної тематики, проповідник користується близькими для себе й сучасників категоріями політико-правових уявлень Речі Посполитої, додаючи до них особливості нового козацько-старшинського політичного устрою. До цієї мішанини додаються апеляції до московського трону, що служать для проповідника ніби «символом» вищої влади православного монарха. Але висловлюючи свою лояльність до Москви, Антоній Радивиловський не заглиблюється в подробиці політичного життя царського двору та його підданих, тож символ залишається лише символом. Ця характеристика є типовою для українських ієрархів, які виявляли зовнішню лояльність до царської влади і навіть служили іiі дипломатичним інтересам, але мали явну 
нехіть до запровадження «московських порядків» на своїй території та обстоювали свою окремішність [1].

Порівняна меншість посилань у проповідях Антонія Радивиловського на образи козацько-старшинського політичного життя та «неувага» до московських порядків свідчить про «річпосполитськість» політичного світогляду проповідника, в якому нерозривно злилися політичні світи Русі та Речі Посполитої (як політичного ладу) з філософськими політико-правовими ідеалами республіканізму та уявленнями про громадянські свободи, що цілком відповідають тенденціям тогочасної політичної та правової філософії.

\section{Список використаних джерел}

1. Броджі-Беркофф Джованна «Мир з Богом чоловіку» як система моральної філософії // Інокентій Гізель: вибрані твори: в трьох томах. Том 3: Дослідження та матеріали / за ред. Довгої Л. М. Київ-Львів: Свічадо, 2010. С. 103-132.

2. Галятовський Іоаникій. Ключ розуміння / підгот. Чепіга І. П. Київ: Наукова думка, 1985. С. 53-238.

3. Довга Л. М. Система цінностей в українській культурі XVII століття. Київ-Львів: Свічадо, 2012. 344 с.

4. Когут Зенон. Коріння ідентичності. Київ: Критика, 2004. 352 с.

5. Радивиловський Антоній. Вінець Христов.... Київ, 1688. 544 арк.

6. Радивиловський Антоній. Вінець Христов...: рукопис: т. 2 / І.Р. ЦНБУ ім. В. І. Вернадського. 1615 с.

7. Радивиловський Антоній. Огородок.... Київ, 1676. 1128 с.

8. Радивиловский Антоний. Слова часу войны // Марковский М. Н. Антоний Радивиловский, южнорусский проповедник XVII века. Киев: Тип. имп. ун-та св. Владимира В. И. Завадского, 1894. 187 с.

9. Яковенко Н. Дзеркала ідентичності. Дослідження з історії уявлень та ідей в Україні XVI-XVIII ст. Київ: Laurus, 2012. 472 с.

10. Яковенко Н. М. Нарис історії середньовічної та ранньомодерної України. Київ: Критика, 2006. 584 с.

Спивак В. В.

\section{ПОЛИТИКО-ПРАВОВЫЕ КАТЕГОРИИ КАК МАРКЕР ИДЕНТИЧНОСТИ В НАСЛЕДИИ АНТОНИЯ РАДИВИЛОВСКОГО}

В статье исследована проблема политической идентичности Антония Радивиловского на основании анализа политико-правового категориального апарата философской составляющей его проповеднического наследия. Сделан вывод о эклектичности его политического мировозрения, в котором со- 
четаются образы и категории политической жизни Руси-Украины, Речи Посполитой, Войска Запорожского и Московского ичарства. Проявляя лояльность к монарху, как образу высшей власти, проповедник склоняется к идеям республиканизма.

Ключевые слова: украинская философия, философия права, политическая философия, барокко, идентичность, самовластие, республиканизм.

Spivak V. V.

\section{POLITICAL AND LEGAL CATEGORIES AS A MARKER OF IDENTITY IN THE HERITAGE OF ANTHONII RADYVYLOVSKYI}

In clause the problem of political identity of Antoniy Radivilovskiy- the Ukrainian preacher and the church thinker of second half XVII century is investigated. The general intellectual background creative thinker and the place of his achievements in the spiritual tradition of the Baroque. Characterized by ideological foundation of his work and defined philosophical problems which drew attention thinker in his sermons. It is concluded that the presence of his homiletic heritage significant philosophical and legal and philosophical and political aspect that makes these works quite promising source for studying the history of Ukrainian philosophy. On the basis of the analysis of moral - ethical, philosophy-political and philosophy-legal components his hand-written and printed sermon heritages, come to light political and legal ideological preferencesof Antoniy Radivilovskiy and political order with which he identifies himself. It is judged about eclecticism of his political outlook in which images and categories of a political life of Russia-Ukraine, Rzeczpospolita, Zaporozhian Host and Moscow are combined. It is established, that showing demonstrative loyalty to the Moscow monarch as to an image of the higher authority, the preacher is declined to ideas of republicanism, characteristic for political way of Rzeczpospolita. The study complements our understanding of the ideological arsenal of political and legal philosophy thinkers Ukrainian Baroque.

Key words: the Ukrainian philosophy, philosophy of law, political philosophy, a baroque, identity, autocracy, republicanism.

УДК 341.492 .2

Гринчак А. А., доцент кафедри державного будівництва,

Національний юридичний університет імені Ярослава Мудрого, м. Харків

\section{ОЗНАКИ ЗЛОЧИНІВ ПРОТИ ЛЮДЯНОСТІ ЗА СТАТУТОМ МІЖНАРОДНОГО КРИМІНАЛЬНОГО ТРИБУНАЛУ ПО КОЛИШНІЙ ЮГОСЛАВІЇ}

Статтю присвячено аналізу ознак злочинів проти людяності за статутом Міжнародного кримінального трибуналу по колитній Югославї та його практики щуодо циих злочинів. Розкрито визначення злочинів проти людяності як таких, щуо 